\title{
Microgravity-induced apoptosis in cultured glial cells
}

\author{
B.M. Uva ${ }^{1}$, M.A. Masini ${ }^{1}$, M. Sturla ${ }^{1}$, F. Bruzzone ${ }^{1}$, M. Giuliani ${ }^{1}$, G. Tagliafierro ${ }^{1}$, and F. Strollo ${ }^{2}$
}

${ }^{1}$ Dipartimento di Biologia Sperimentale, Ambientale ed Applicata. Università di Genova, V.le Benedetto XV n. 5, 16132 Genova, Italy and ²Unità Endocrinologica, "INRCA” Università "La Sapienza" via Cassia, 00189, Roma, Italy

Accepted: 4/02/02

Key words: microgravity, apoptosis, glial cells

\section{SUMMARY}

Apoptosis is a form of naturally occurring cell death that plays fundamental roles during embryonic developement. In adults, it neatly disposes of cells damaged by injuries provoked by external causes such as UV radiation, ionisation and heat shock. Alteration of the gravity vector may be one of the external apoptosis inducers. Neurophysiological impairment signs were seen during space flights in astronauts, but very few studies were carried out on the nervous system and none at the cellular level. In this study, we submitted cultured $\mathrm{C}_{6}$ glioma cells to microgravity $(0 \mathrm{xg})$ of varying duration, obtained by clinorotation in a Fokker three-dimensional clinostat for $15 \mathrm{~min}, 30 \mathrm{~min}, 1 \mathrm{~h}, 20 \mathrm{~h}$ or $32 \mathrm{~h}$. After $30 \mathrm{~min}$ at 0xg, numerous nuclei underwent the classical morphological alterations (chromatin condensation, nuclear fragmentation, apoptotic bodies) that lead to the programmed cell death. After 30min at 0xg, immunostaining for the enzyme caspase-7 was present in the cytoplasm of many cells concurrently with DNA fragmentation identified by the TUNEL method. At 32h, the number of apoptotic nuclei was much reduced indicating the ability of glial cells to adapt to altered gravity.

\section{INTRODUCTION}

Apoptosis, also called programmed cell death, is a multistep process characterised by cell shrinkage, chromatin condensation, DNA dissassemblation, nuclear fragmentation, and packaging of the nuclear fragments into apoptotic cell bodies (Wyllie et al., 1980): all these events lead to the death of the cell. Apoptosis is needed during embryonic development to shape organs and tissues, but it may occur to remove, in a neat, orderly way, damaged cells in the adult. Extreme insults, such as ionising or UV radiation, heat shock or hypoxia, as well as environmental stresses such as hyperosmolarity (Pellicciari et al., 2000), may activate signals that induce apoptosis. Gravitational force alteration may also be one of those triggering inputs. Apoptosis was observed in lymphocytes (Jurkat) during spaceflight (Lewis et al., 1998; Cubano and Lewis, 2000). Gravity vector changes, in fact, have been reported to damage the cytoskeleton of lymphocytes (Gmunder et al., 1990; Cogoli-Greuter et al., 1994; Lewis et al., 1998; Hashemi et al., 1999; Walther et al., 1999) and of HL-60 promyelocytes in culture (Piepmeier et al., 1997), both during space flight and in simulated microgravity on ground-conducted experiments. In previous experiments, we observed severe damages to the cytoskeleton of cultured glial cells submitted 
on-ground to simulated microgravity (Uva et al., 2000; Uva et al., 2001a,b); nuclear alterations were also observed (Uva et al., 2001c). Glial cells are the most numerous type of cells in the mammalian nervous system. Neuroglia interact with neurons in a complex way; besides being fundamental for nutrition, they are also fundamental, for neurogenesis, neural regeneration and signal transmission. Damage at the glial cell level leads to impairment of the entire nervous system. Neurophysiological problems were reported to occur in astronauts during space flights (Krasnov, 1994), but very few studies were performed on the nervous system and none at the cellular level.

The aim of this study was to investigate if weightlessness, which has been proved to cause cytoskeletal alterations, may induce programmed cell death in glial cells. We analysed the morphological evidences of apoptosis in cultured $\mathrm{C}_{6}$ glioma cells, submitted on-ground to simulated microgravity, using the nuclear stains 4,6-diamidino-2-phenylindole, dihydrochloride (DAPI) and propidium iodide. Simulated microgravity was obtained using the so called "clinostat", a random positioning machine that simulates some of the physical effects of space flight by providing a vector averaged reduction of the apparent gravity without generating significant shear forces (Gmunder et al., 1990). DNA fragmentation in situ was identified by a method based on the incorporation of biotinylated nucleotides, mediated by a terminal deoxynucleotidyltransferase (TdT), into the 3' ends of DNA fragments [terminal dUTP nick end labelling (TUNEL)] (Gavriely et al., 1992). The presence of caspases (cysteinyl aspartate specific proteases), a family of cysteine proteases whose activation causes death by apoptosis (Alnemry et al., 1996), was determined by investigating the presence of caspase-7; this enzyme is thought to coordinate the execution phase of apoptosis by cleaving multiple structural and repair proteins (Slee et al., 2001) and is expressed in glioma cell lines (Glaser and Weller, 2001).

\section{MATERIALS AND METHODS}

\section{Cell and culture procedure}

$\mathrm{C}_{6}$ glioma cells (kindly provided by prof. C. Pellicciari, University of Pavia, Italy), a cell line derived from rat brain tumor, were grown in D-MEM medium (Sigma, St. Louis, MO) with the addition of $10 \%$ foetal bovine serum, $1 \%$ gentamycin and $1 \%$ L-glutamine (Celbio, Milano, Italy).
For the experiments, cells were placed in monolayer cultures in flasks on slides. The flasks on slides were positioned in a random positioning machine (Fokker three-dimensional clinostat kindly provided by Prof. P. Pippia, University of Sassari, Italy) and kept under continuous rotation at 60 $\mathrm{rpm}$ for $15 \mathrm{~min}, 30 \mathrm{~min}, 1 \mathrm{~h}, 20 \mathrm{~h}$ and $32 \mathrm{~h}$ (simulated microgravity, 0xg). Ground (1xg) controls, kept in an identical machine and treated in parallel, were placed onto the supporting frame of the machine to subject the cells to the same vibrations. At the end of each experiment, the flasks were filled with phosphate buffered saline (PBS) containing $4 \%$ paraformaldehyde.

\section{Staining procedure and immunohistochemistry}

The slides were removed from the flasks and submitted to staining procedures and immunohistochemistry. Slides with cultured cells submitted to different duration 0xg conditions underwent the indirect immunofluorescence technique (Coons et al., 1955). After permeabilisation with $0.1 \%$ Triton $\mathrm{X}-100$ (Sigma) and exposure to normal goat serum (diluted 1:50; Sigma) at $20^{\circ} \mathrm{C}$ in a moist chamber, the cells were incubated overnight at $4^{\circ} \mathrm{C}$ with the antiserum Ab-caspase-7 (Purified, Active), raised in rabbits (diluted 1:200, Alexis, Biochemical, San Diego, USA). After washing in 0.01 M PBS, pH 7.4, cells were incubated for $30 \mathrm{~min}$ in a moist chamber at $20^{\circ} \mathrm{C}$ with fluorescein-isothiocyanate (FITC)conjugated anti-rabbit IgG raised in goat (diluted 1:100, Sigma). The slides were rinsed in PBS and mounted with gel-mount (Biomeda Corp., Foster City, CA). The specificity of the immunostaining was verified by omitting one of the steps of the immunohistochemical procedure, or by replacing the primary antiserum with non-immune rabbit serum or PBS. DNA fragmentation was visualised with TUNEL (in situ cell death fluorescein detection kit, Roche Diagnostic Co., Indianapolis, IN., USA) The nuclear alterations were observed with a conventional epifluorescence microscope (Olympus). Nuclei were stained for two hours with $1 \mathrm{ml}$ PBS containing $5 \mathrm{mg} / \mathrm{ml}$ propidium iodide, !00 $\mathrm{U} / \mathrm{ml}$ RNase or 4,6-diamidino-2-phenylindole, dihydrochloride (DAPI).

Percentage of altered cells was counted in each experiments from control and treated cultures. Data are expressed as mean and standard deviations of the percent of cells calculated from three randomly chosen fields in two slide preparations for each sample. 
Table I

Percentage of altered nuclei to simulated microgravity at different exposure times (means $\pm \mathrm{SD}$ )

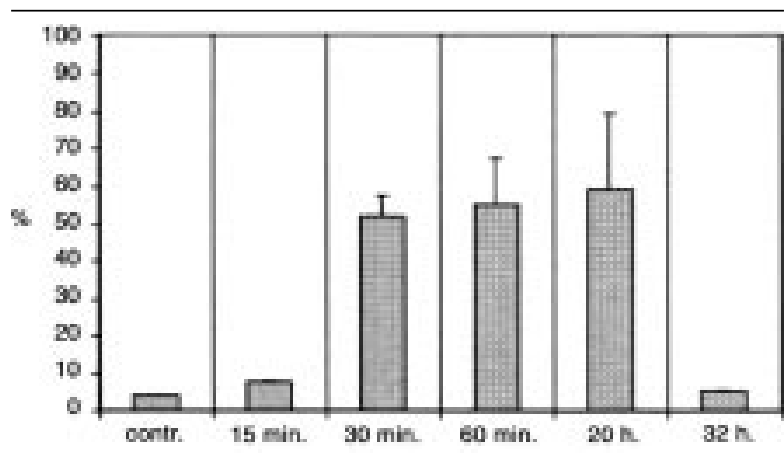

\section{RESULTS}

We monitored alterations occurring in the $\mathrm{C}_{6}$ cultured glioma cells submitted to simulated microgravity for $15 \mathrm{~min}, 30 \mathrm{~min} 1 \mathrm{~h}, 20 \mathrm{~h}$ and $32 \mathrm{~h}$. From $15 \mathrm{~min}$ to $20 \mathrm{~h}$ at simulated $0 \mathrm{xg}$, the percentage of altered nuclei increased, while in the controls it remained as low as $4.01 \%$. After $32 \mathrm{~h}$ at $0 \mathrm{xg}$, the percentage of the altered cells was back in the range of 5\%, as was that of the control cultured cells (Table I), but the density of the cell populations was much lower than that of the controls (20\%).

After $30 \mathrm{~min}, 1 \mathrm{~h}$ and $20 \mathrm{~h}$ at $0 \mathrm{xg}$, the chromatin was condensed in patches in altered nuclei (Fig. $1 b, c)$ and binucleated cells were frequently seen (Fig. 1d). Nuclear blebbing was numerous (Fig. 2d), micronuclei were present in the cytoplasm, and cellular shrinkage and nuclear fragmentation were found in almost all the altered cells after $20 \mathrm{~h}$ at $0 \mathrm{xg}$ (Fig. 2b,c).

A TUNEL-positive DNA fragmentation pattern was easily identified in nuclei starting at $30 \mathrm{~min}$ at 0xg (Fig. 3b). In binucleated cells, the nuclei were TUNEL-positive as were the micronuclei and the nuclear blebs (Fig. 3d,f).

Immunostaning for caspase-7 was identified in the cytoplasm of many cells after $30 \mathrm{~min}$ at simulated $0 \mathrm{xg}$; the immunostaining was stronger in cells with nuclei showing highly condensed chromatin (Fig. 4a,b).

TUNEL-positivity and immunoreaction for
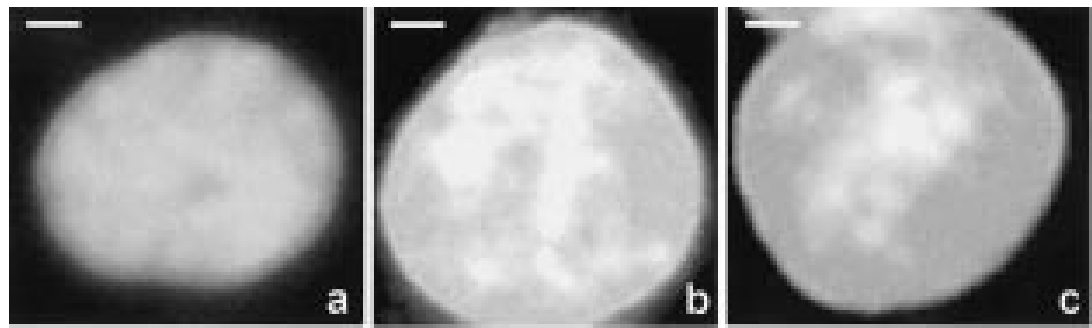

Fig. 1 - Nuclei of DAPI-stained cells show characteristic chromatin condensation (white spots) after 30min (b) and $1 \mathrm{~h}(\mathrm{c})$ at $0 \mathrm{xg}$. In (d), a binucleated cell after $20 \mathrm{~h}$ at $0 \mathrm{xg}$, stained with propidium iodide. In (a), DAPI stained nucleus in a control cell (1xg). Bars: $0.6 \mu \mathrm{m}$.
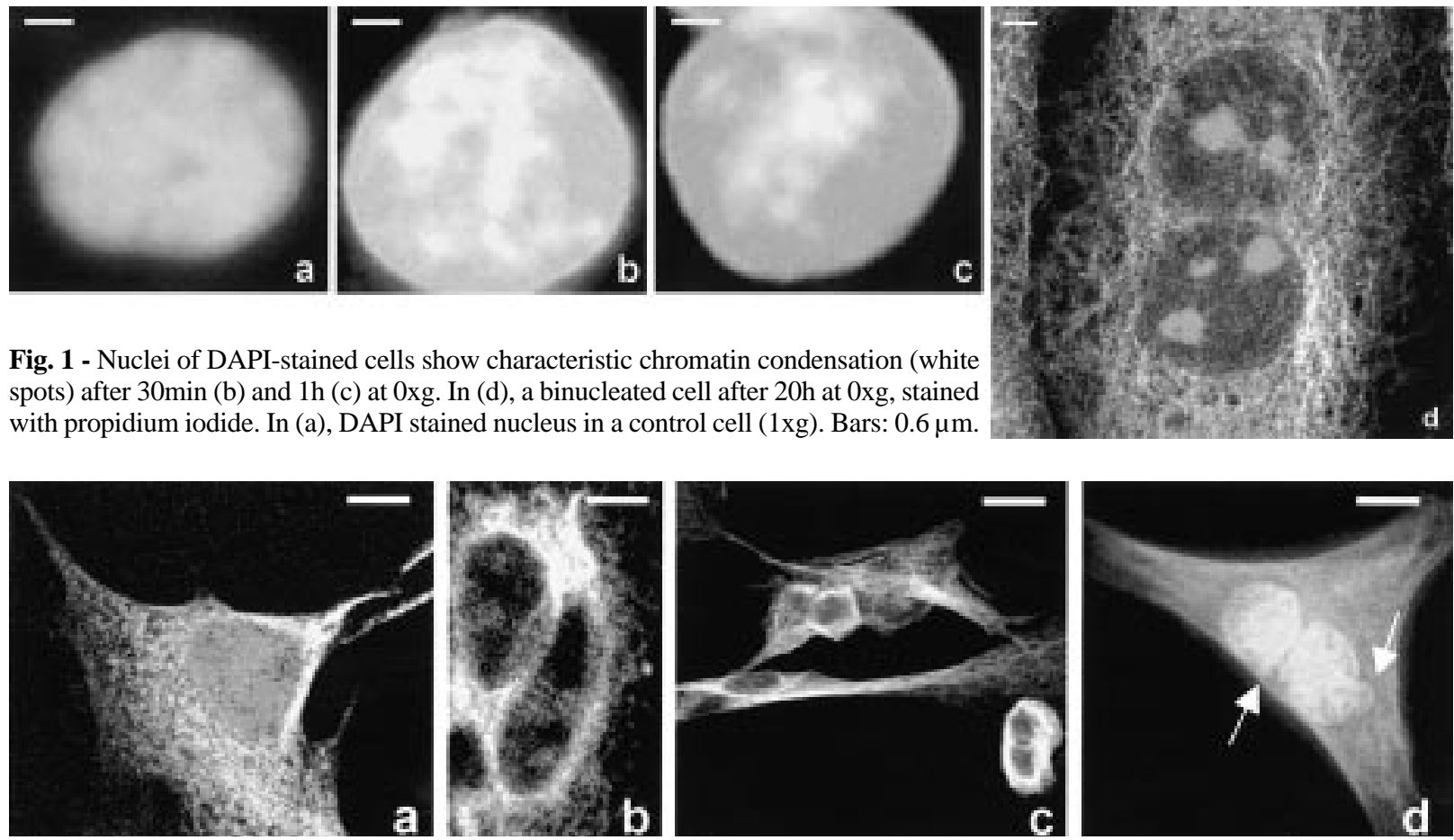

Fig. 2 - (a) Control normal cell, 1xg; (b) apoptotic cell with fragmented nucleus after 20h of simulated microgravity; (c) cell shrinkage after $20 \mathrm{~h}$ at $0 \mathrm{xg}$; (d) nuclear blebs (arrows) after 30min at simulated 0xg. Nuclei were stained with propidium iodide (a,b.c) or DAPI (d). Microtubules were immnostained with Ab-a tubulin. Bars: $2 \mu \mathrm{m}$ (a); $1.5 \mu \mathrm{m}$ (b); $0.5 \mu \mathrm{m}$ (c); $2.2 \mu \mathrm{m}$ (d). 

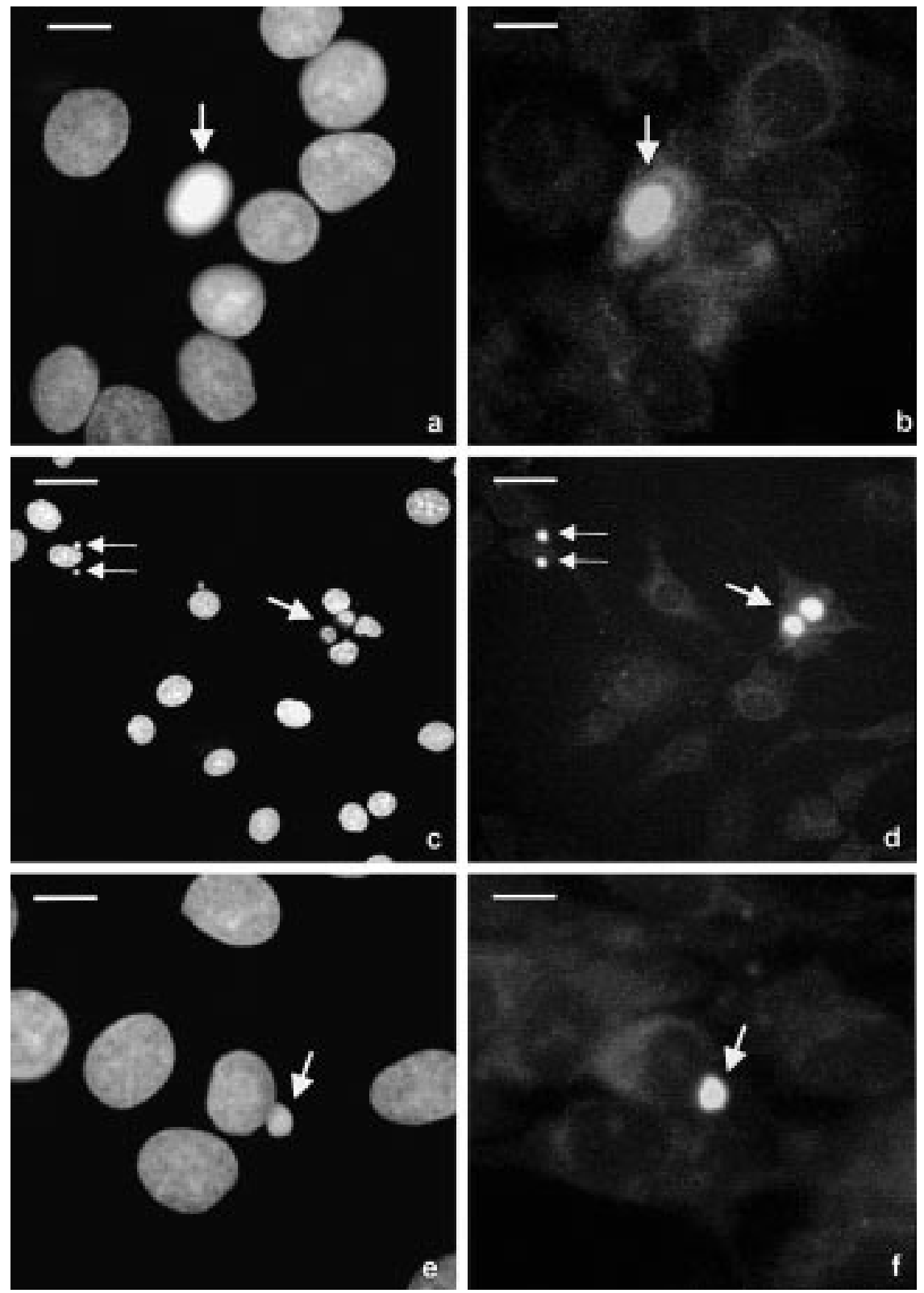

Fig. 3 - Cells after 1 h at simulated microgravity. a,c,e: DAPI stained nuclei; b,d,f: TUNEL positivity in the same cells as a,c,e. The intense reaction in (b) corresponds to a nucleus with highly condensed chromatin (a) (arrows). TUNEL stained binucleated nuclei and micronuclei (arrows) in (d) correspond to the DAPI-stained cells in (c). TUNELpositive nuclear bleb in (f) corresponds to a bleb with condensed chromatin in (e) (arrows). Bars: 2.8 $\mu \mathrm{m}(\mathrm{a}, \mathrm{b}) ; 8 \mu \mathrm{m}(\mathrm{c}, \mathrm{d}) ; 2.8 \mu \mathrm{m}(\mathrm{e}, \mathrm{f})$.

caspase-7 were much less evident in the control cultured cells positioned onto the support frame of the clinostat. Immunohistochemical controls yielded negative results.

\section{DISCUSSION}

The present study shows that a time-dependent microgravity-related apoptosis occurs in cultured glial cells submitted to simulated microgravity (0xg) obtained by clinorotation using a Fokker three-dimensional clinostat. The presence of typical events such as cell shrinkage, chromatin condensation, nuclear fragmentation, micronuclei formation and apoptotic bodies suggest that microgravity-induced apoptosis occurs through the well-known series of morphological events. Apoptosis was identified in Jurkat cells flown in the Space Shuttle (Cubano and Lewis, 2000) on 

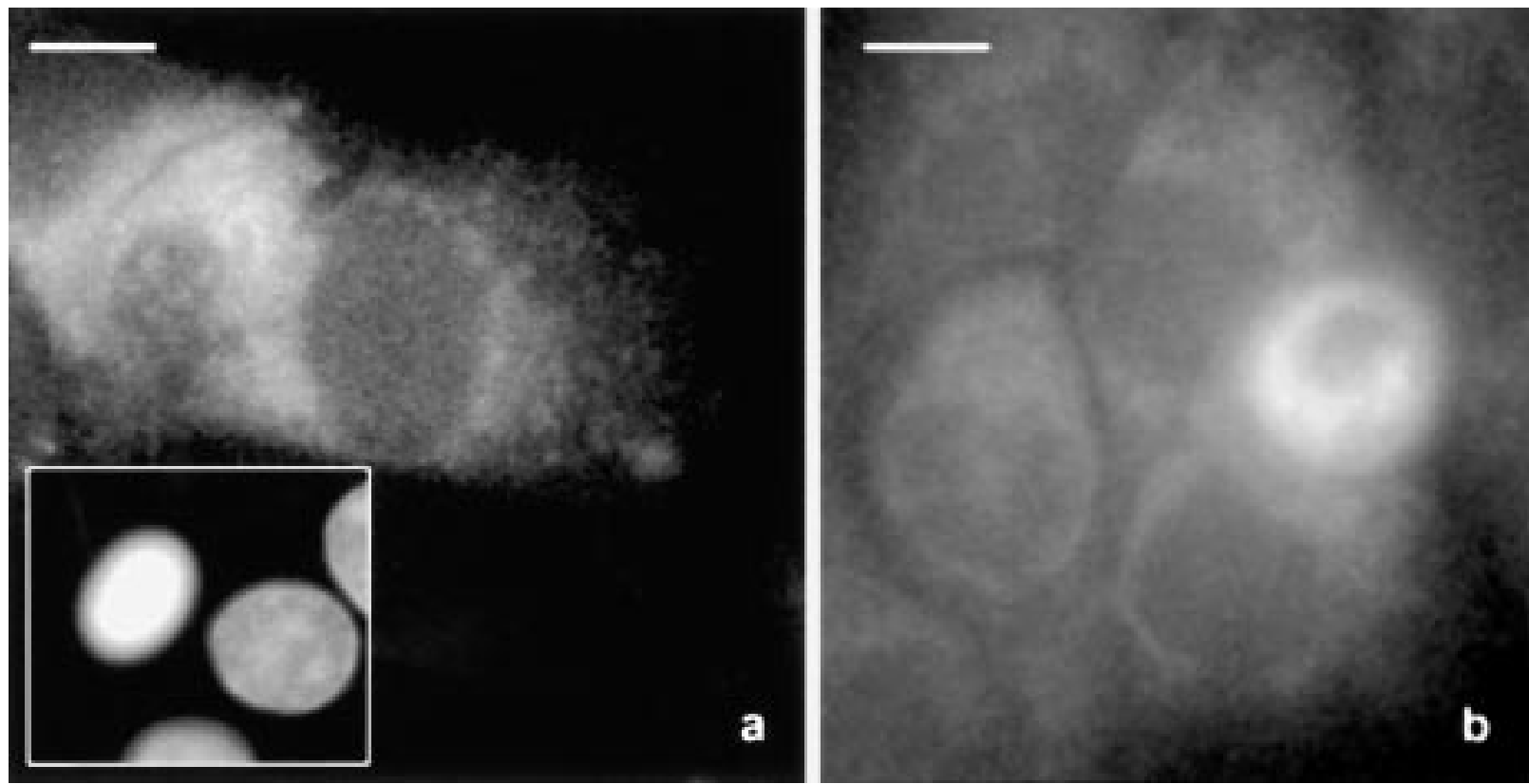

Fig. 4 - Caspase-7 immunostaining in apoptotic cells after 1h (a) and $30 \mathrm{~min}$ (b) of simulated microgravity. In (a), the insert shows, in the same field, a DAPI-stained nucleus with condensed chromatin. Bars: $2.1 \mu \mathrm{m}$ (a); $2.4 \mu \mathrm{m}$ (b).

the basis of nuclear morphology and the presence of the cell death factor sFAS/APO-1. In those experiments, apoptosis was microgravity-dependent and time-dependent, reaching the maximum density of apoptotic nuclei a $4 \mathrm{~h}$.

In our experiments, apoptotic nuclei began to be observed after $30 \mathrm{~min}$ at $0 \mathrm{xg}$, increased until $20 \mathrm{~h}$ and then were almost absent at $32 \mathrm{~h}$. The presence of caspase-7, one of the major contributors to the enymatic cascade leading to apoptosis, was detected in the cytoplasm starting at $30 \mathrm{~min}$ at $0 \mathrm{xg}$. Caspase-7 cleaves many of the same substrates as caspase-3, including poly (ADP-ribose) polymerase (PARP) (Germain et al., 1999) and the structural components of the nuclear lamina, a rigid structure underlying the nuclear membrane and is involved in chromatin organisation. The lamina is formed by proteins called lamins. By disrupting lamins, caspases cause lamina to collapse and chromatin to condense (for a review see Thornberry and Lazebnik, 1998). DNA fragmentation, evidenced by the TUNEL method, is also present after $30 \mathrm{~min}$ at $0 \mathrm{xg}$.

All these data indicate that cells were affected by weightlessness within minutes, during which time apoptosis was induced. It has been reported that apoptosis affects the cytoskeleton, particularly actin microfilaments (Spano et al., 2000). However, one cannot exclude that things might go the other way round: an alteration in the cytoskeleton might be one of the inducers of cell death. Interaction between central spindle microtubules and cortical actin filaments leads to cytokinesis. When either of these structures is perturbed, cell division is suppressed (Gatti et al., 2000); binucleated cells may frequently be formed and cell death may be induced. According to this view, cytoskeletal changes observed in lymphocytes and glial cells after weightlessness might be the endogenous stimulus triggering apoptosis.

Long-term experiments showed that cells are able to adapt to changes in the gravitational field, and to reorganise their cytoskeleton (Uva et al., 2000, 2001a,b). In the present study, we observed that the number of apoptotic nuclei dramatically decreased from $20 \mathrm{~h}$ to $32 \mathrm{~h}$ : once more this underlines the high plasticity of glial cells and suggests the reasonable hypothesis that the absence of gravity may induce only transient alterations in the glial cells.

\section{ACKNOWLEDGEMENTS}

This work was supported by the Italian Space Agency (ASI) Grant I/R/149/00. Thanks are due to $\mathrm{Mr}$. Campus for the valuable technical support during the clinorotation experiments. 


\section{REFERENCES}

Alnemry E.S., Livingston D.J., Nicholson D.W., Salvesen G., Thornberry N.A., Wong W.W., and Yuan J.Y.: Human ICE/CED-3 protease nomenclature. Cell 87, 171, 1996.

Cogoli-Greuter M., Pippia P., Siola I., and Cogoli A.: Lymphocytes on sounding rocket flights. J. Gravit. Physiol. 1, 9091, 1994.

Coons A.H., Leduc E.H., and Connolly J.M.: Studies on antibody. I. A method for the histochemical demonstration of specific antibody and its application to a study of the hyperimmune rabbit. J. Exper. Med. 102, 49-59, 1955.

Cubano L.A. and Lewis M.L.: Pas/APO-1 protein is increased in spaceflown lymphocytes (Jurkat). Experimental Gerontology $35,389-400,2000$

Gatti A.U., Giansanti M., and Bonaccorsi S.: Relationship between the central spindle and the contractile ring during cytokinesis in animal cells. Microsc. Res. Tech. 49, 202-208, 2000.

Gavrieli Y., Sherman Y., and Brn-Sasson S.A.: Identification of programmed cell death in situ via specific labeling of nuclear DNA fragmentation. J. Cell Biol. 119, 493-501, 1992.

Germain M., Affar E.P., D’ Amours D., Dixit V.M., Salvesen G.S., and Poirier G.G.: Cleavage of automodified poly (ADPribose) polymerase during apoptosis. Evidence for involvement of caspase-7. J. Biol. Chem. 274, 28379-28384, 1999.

Glaser T., and Weller M.: Caspase-dependent chemotherapyinduced death of glioma cells requires mitochondrial cytochrome c release. Biochem. Biophys. Res. Commun. 281, 322-327, 2001

Gmunder F.H., Kiess M., Sonnefeld G., Lee G., and Cogoli A.: A ground-based model to study the effects of weightlessness in lymphocytes. Biol. Cell. 70, 33-38, 1990.

Hashemi B.B., Penkala J.E., Vens C., Huls H., Cubbage M., and Sams C.F.: T cell activation responses are differently regulated during clinorotation and spaceflight. FASEB J. 13, 2071-2082, 1999.

Krasnov I.B.: Gravitational neuromorphology. Adv. Space. Biol. Med. 4, 85-110,1994.

Lewis M., Reynolds J.L., Cubano L.A., Hatton J.P., Lawless B.D., and Piepmeier E.H.: Spaceflight alters microtubules and increases apoptosis in human lymphocytes (Jurkat). FASEB J. 12, 1007-1018, 1998

Pellicciari C., Bottone M.G., Scovassi A.I., Martin T.E., and Biggiogera M.: Rearrangement of nuclear ribonucleoproteins and extrusion of nucleolus-like bodies during apoptosis induced by hypertonic stress. Eur. J. Histochem. 44, 247-254, 2000

Piepmeyer E.H., Kalns J.E., McIntyre K.M., and Lewis M.: Prolonged weightlessness affects promyelocytic multidrug resistance. Exp. Cell Res. 237, 410-418, 1997.

Slee E.A., Adrian C., and Martin S.J.: Executioner caspase-3, -6 , and -7 perform distinct, non reduntant roles during demolition phase of apoptosis. J. Biol. Chem. 276, 7320-7326, 2001.

Spano A., Sciola L., Monaco G., and Barni S.: Relationship between actin microfilaments and plasma membrane changes during apoptosis of neoplastic cell lines in different culture conditions. Eur. J. Histochem. 44, 255-267, 2000

Thornberry N.A., and Lazebnik, Y.: Caspases: enemies within. Science 281, 1312-1316, 1998.

Uva B.M., Masini M.A., Sturla M., Prato P., and Tagliafierro G.: Effect of microgravity on the cytoskeleton of cultured nervous cells. Gravitat. And Space Biol. Bull. 14 (1), 53, 2000.

Uva B.M., Masini M.A., Sturla M., Prato P., Passalacqua M., Giuliani M., Strollo F., and Tagliafierro G.: Simulated microgravity induces alteration in the central nervous system. J. Gravitational Physiol., 8, 93-95, 2001a.

Uva B.M., Masini M.A., and Strollo F.: Cytoskeletal alteration in cultured glial cells submitted to simulated microgravity. Microgravity and Space Station Utilization-MSSU, 2, 263-264, 2001b.

Uva B.M., Masini M.A., Tagliafierro G., and Strollo F. Nuclear alterations in cultured glial cells submitted to simulated microgravity. Bullettin of the European Low Gravity Research Association 22, 57-58, 2001c.

Walther I., Cogoli A., Pippia P., Meloni M.A., Cossu G. Cogoli M., Schwarzenberg M, Turrini F. and Mannu F.: Human immune cells as space travelers. Eur. J. Med. Res. 4 361-363, 1999.

Wyllie A.H., Kerr J.F.K. and Currie A.R.: Cell death: the significance of apoptosis. Int. Rev. Cytol. 68, 251-306, 1980. 